\title{
The Potential of Carbon and Chlorophyll Concentration on Phytoplankton in Lakes at Campus Universitas Indonesia, Depok
}

\author{
Sumiriyati, Anggari Kirana Dewi
}

\begin{abstract}
Lakes has potential as a carbon sink in the waters. Primary productivity is the rate of formation of organism compound from the energy rich inorganic compounds. This study is about the level of carbon uptake and chlorophyll content on phytoplankton, is aims to analyze the level of carbon uptake study was conducted in six lakes Campus University of Indonesia Depok, namely Kenanga, Agathis, Mahoni, Puspa, Ulin and Salam. Sampling was conducted in September-October 2015. The dark-light bottle method used to measure the primary productivity in the waters. Bottle of darks and light was placed at a dept of $0 \mathrm{~cm}, 10 \mathrm{~cm}, 30 \mathrm{~cm}, 50 \mathrm{~cm}$ and $70 \mathrm{~cm}$. Sampling of phytoplankton was conducted using a plankton net. Measurement of chlorophyll-a, chlorophyll-b and chlorophyll-c using a spectrophotometer with a wavelength of $750,664,647$ and $630 \mathrm{~nm}$. The rate of carbon uptake in six lakes Campus University of Indonesia Depok it has potential to absorb carbon average between 0.442--0.879 $\mathrm{mgC} / \mathrm{m}^{3} /$ hour. The content of chlorophyll-a, chlorophyll-b and chlorophyll-c, largest average in a row is obtained in Agathis Lake is $0.135 \mathrm{mg} / \mathrm{l}$, Kenanga Lake is $0.095 \mathrm{mg} / \mathrm{l}$ and Kenanga Lake is $0.116 \mathrm{mg} / \mathrm{l}$. The smallest average in a row is Kenanga lake is $0.012 \mathrm{mg} / \mathrm{l}$, Puspa 0.016 lake is $\mathrm{mg} / \mathrm{l}$ and Agathis lake $0.003 \mathrm{mg} / \mathrm{l}$. The results of the identification of phytoplankton samples obtained in class Chlorophyta, Cyanobacteria and Bacillariophyta (Diatom)
\end{abstract}

Keywords--- Carbon, phytoplankton, primary productivity, chlorophyll, University of Indonesia Depok.

\section{INTRODUCTION}

Phytoplankton are group of plankton that has pigment of chlorophyll. Therefore phytoplankton can do the process of photosynthesis to form organic substances from inorganic substances. The ability to perform photosynthesis cause phytoplankton has a major role as producers in aquatic ecosystems [5].

Phytoplankton can generally be divided into two groups based on the shape of the cell, namely unicellular with a size of about $2 \mu \mathrm{m}$ and multicellular or shaped like a thread (filament) with a length of up to $8 \mu \mathrm{m}$. Freshwater phytoplankton are dominated by Cyanophyta (Cyanobacteria), Chlorophyta, Bacillariophyta (diatoms) and Euglenophyta [5].

Department of Biology, Faculty of Mathemathics and Natural Sciences, University of Indonesia, Depok 16424, Indonesia
Chlorophyll is a pigment in the chloroplasts utilized by phytoplankton in photosynthesis process which is found in all autotrophic organisms [4]. Chlorophyll-a is a pigment which could absorb and distribute energy directly from sunlight during photosynthesis, while other pigments such as chlorophyll-b and chlorophyll-c could only distribute the light energy absorbed by chlorophyll-a. Chlorophyll-a is able to absorb sunlight at wavelengths less than $460 \mathrm{~nm}$ (blue) and 630-670 nm (red) [2].

Phytoplankton plays an important role as a producer of carbon through photosynthesis. In general, the primary productivity of water is controlled by environmental conditions, such as solar radiation, nutrient availability, and the ability of photosynthetic phytoplankton species. The rate of primary productivity will be high if the environmental factors are suitable or optimal. Measurements of primary productivity is generally based on the rate of photosynthesis.

Potential of carbon concentration related to the concentration of chlorophyll in phytoplankton for photosynthesis process itself influenced by the concentration of chlorophyll, especially chlorophyll-a, as well as the intensity of sunlight. Primary productivity value can be used as an indication of the fertility level an aquatic ecosystem. Chlorophyll-a highly affect the size of primary productivity in the waters. Therefore, chlorophyll-a concentrations in an aquatic ecosystem can be used as one of the indicator of abundance of phytoplankton which can be indicated from the primary productivity associated with potential carbon sink of phytoplankton.

The information on the relationship between primary productivity with the concentration of chlorophyll-a and its relationship with the factor of chemical-physics of the lakes in University of Indonesia during dry season are still very limited. Therefore, it is necessary to determine the concentration of chlorophyll phytoplankton in relation to primary productivity and carbon sink in the dry season, because the season is one of the limiting factor of primary productivity.

This study was conducted to analyze the potential of the carbon content and chlorophyll phytoplankton, in six lakes University of Indonesia, Depok. 


\section{MATERIAL AND METHODS}

The research was conducted on September-October 2015 at six lakes located in University of Indonesia, Depok, West Java, Indonesia. Those six lakes are Kenanga lake $\left(28.000 \mathrm{~m}^{2}\right)$, Ulin lake $\left(72.000 \mathrm{~m}^{2}\right)$, Puspa lake $\left(20.000 \mathrm{~m}^{2}\right)$, Mahoni lake $\left(45.000 \mathrm{~m}^{2}\right)$, Salam lake $\left(42.000 \mathrm{~m}^{2}\right)$, and Agathis lake $\left(20.000 \mathrm{~m}^{2}\right)$. (Fig. 1). Samples were taken at three different predetermined sites (Inlet, middlet and outlet).

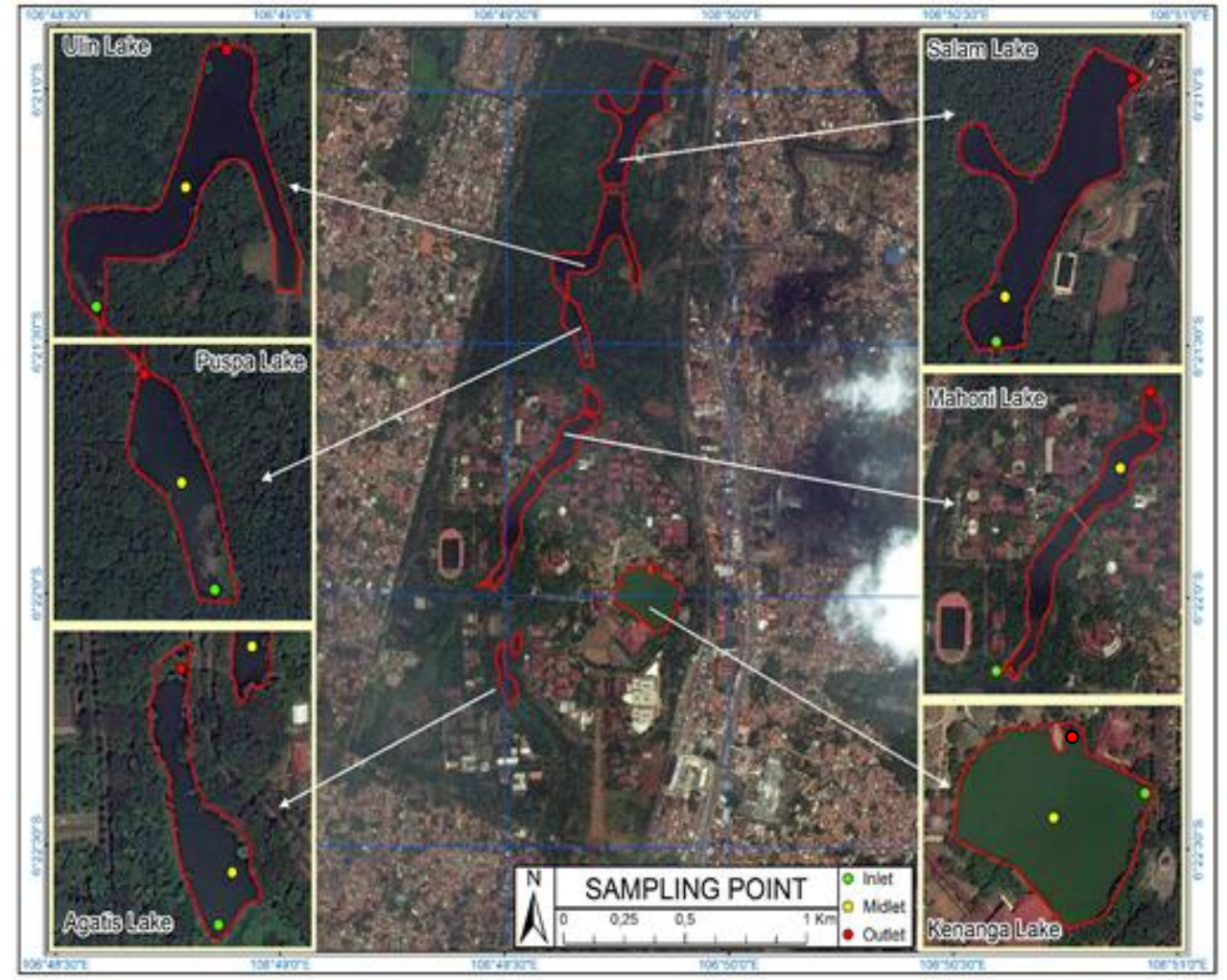

Fig. 1. Location sampling point at six lakes in University of Indonesia

All samples were gathered within a week and the phytoplankton samples were analyzed absorbance for two weeks. The ingredient of nitrate and phosphate were processed with spectrophotometry methods.

The dark-light bottle method used to measure the primary productivity in the waters. Bottle of darks and light was placed at a dept of $0 \mathrm{~cm}, 10 \mathrm{~cm}, 30 \mathrm{~cm}, 50 \mathrm{~cm}$ and $70 \mathrm{~cm}$. Sampling of phytoplankton was conducted using a plankton net. Measurement of chlorophyll-a, chlorophyll-b and chlorophyll-c using a spectrophotometer with a wavelength of $750,664,647$ and $630 \mathrm{~nm}$.

Measurement of carbon concentration, calculated with formula [1]:

Respiration $(\mathrm{R})=\left[\mathrm{O}_{2}\right]_{\text {first }}-\left[\mathrm{O}_{2}\right]_{\text {last }}$ on the dark bottle

Gross primary productivity $(\mathrm{GPP})=$

$\left[\mathrm{O}_{2}\right]_{\text {last }}$ on the dark bottle- $\left[\mathrm{O}_{2}\right]_{\text {last }}$ on the dark bottle

Net Primary Productivity $(\mathrm{NPP})=$ Gross

primary productivity (GPP) - Respiration (R)

Converted number from $\mathrm{mg} / \mathrm{l}$ Oxygen to $\mathrm{mgC} / \mathrm{m}^{3} /$ hour, then the number from $\mathrm{mg} / \mathrm{l}$ times to factor 375.36 . Then to get primary productivity number each hour, the result divided to six $\left(\mathrm{mgC} / \mathrm{m}^{3} /\right.$ hour$)$. The environment parameter measurement according in lakes including $\mathrm{pH}$, temperature, light penetration, turbidity, dissolved oxygen, nitrate and phosphate.

\section{RESULTS AND DISCUSSION}

The rate of carbon uptake in six lakes of University of Indonesia, Depok have potential to absorb carbon average between $0.442--0.879 \mathrm{mgC} / \mathrm{m}^{3} /$ hour. The content of chlorophyll-a, chlorophyll-b and chlorophyll-c, largest average in a row is obtained in Agathis Lake is $0.135 \mathrm{mg} / \mathrm{l}$, Kenanga Lake is $0.095 \mathrm{mg} / \mathrm{l}$ and Kenanga Lake is $0.116 \mathrm{mg} / \mathrm{l}$. The smallest average in a row is Kenanga lake is $0.012 \mathrm{mg} / \mathrm{l}$, Puspa 0.016 lake is $\mathrm{mg} / \mathrm{l}$ and Agathis lake $0.003 \mathrm{mg} / \mathrm{l}$. The results of the identification of phytoplankton samples obtained in class Chlorophyta, Cyanobacteria and Bacillariophyta ( Diatom). 
TABLE I: RESUlt OF OBSERVATION AT SiX LAKES

\begin{tabular}{llllll}
\hline & & \multicolumn{3}{l}{ Chlorophyll(mgl) } & \\
\cline { 3 - 5 } Number & Lakes & A & B & C & Carbon Total (mgC/m3 hour) \\
\hline 1 & Agathis & 0.135 & 0.049 & 0.003 & 0.499 \\
2 & Mahoni & 0.078 & 0.08 & 0.085 & 0.8 \\
3 & Puspa & 0.042 & 0.016 & 0.046 & 0.487 \\
4 & Ulin & 0.092 & 0.025 & 0.036 & 0.442 \\
5 & Salam & 0.102 & 0.039 & 0.048 & 0.879 \\
6 & Kenanga & 0.012 & 0.095 & 0.116 & 0.448 \\
\hline & Averages & 0.079 & 0.051 & 0.057 & 0.631 \\
\hline
\end{tabular}

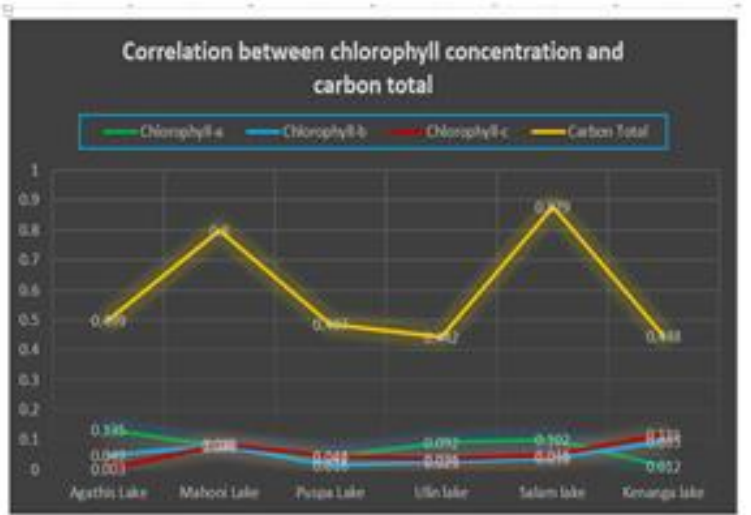

Fig. 2. Corelation between chlorophyll contain and carbon sink

TABLE II: ENVIRONMENT PARAMETER

\begin{tabular}{|c|c|c|c|c|c|c|c|c|}
\hline Samplinģ Point & $\begin{array}{l}\text { Light } \\
\text { (Lux) }\end{array}$ & $\begin{array}{l}\text { Temperature } \\
\text { (c) }\end{array}$ & $\mathrm{PH}$ & Turbidity & $\operatorname{Depth}(\mathrm{m})$ & $\begin{array}{l}\text { Dissolved } \\
\text { Oxygen }\end{array}$ & $\begin{array}{l}\text { Content } \\
Y(p p m)\end{array}$ & $P(p m p)$ \\
\hline Agathis Lake & 4.82 & 30.82 & 7.33 & 27.5 & 46 & 0.15 & 25.7 & 1.053 \\
\hline Maboui Lake & 52.71 & 32.83 & 6.67 & 16.16 & 54.67 & 2.23 & 13.48 & 0751 \\
\hline Plspa Lake & 49.68 & 33.16 & 5 & 25.16 & 109.6 & 0.26 & 1233 & 0.376 \\
\hline Ulin Lake & 4.82 & 29.93 & 6.33 & 17.41 & 122 & 0.53 & 5.51 & 0.183 \\
\hline Kenanga Lake & 24.16 & 28 & j & 15.75 & 129.67 & 0.36 & 6.57 & 0.168 \\
\hline Salam Lake & 52.13 & 31 & 5.67 & 38.67 & 213.67 & 1 & 4.54 & 0.0037 \\
\hline Arergage & 38.033 & 30.9567 & 6 & 23.442 & 112.602 & 0.755 & 11.355 & 0.422 \\
\hline
\end{tabular}

The average of light intensity in Agathis, Mahoni, Puspa, Ulin, Kenanga and Salam lakes range from 4.82 to 52.71 lux. The occurrence of the difference in intensity of light is far between Agathis lakes and mahoni lakes, that is can be caused by differences time during sampling. The high intensity of light in Mahoni lakes make the amount of phytoplankton through photosynthesis becomes larger, caused increasing primary productivity on the waters.

The average temperature in Agathis, Mahoni, Puspa, Ulin, Kenanga and Salam lakes range between $28--33.16^{\circ} \mathrm{C}$. The temperature range can support photosynthesis process by phytoplankton in the waters, because photosynthesis can take optimally photosynthesis at a temperature of $25--40^{\circ} \mathrm{C}$. High and low temperature of the water can be influenced by several factors, including the intensity of light, heat exchange with the waters surrounding waters and the canopy (closing by vegetation) from the plant nearby The average $\mathrm{pH}$ in Agathis,
Mahoni, Puspa, Ulin, Kenanga and Salam lakes range from 5 to 7.33. The $\mathrm{pH}$ value range can support life aquatic organisms, due to the optimal $\mathrm{pH}$ for the life of aquatic organisms including plankton range from 7 to 8.5 [3]. The more the number of phytoplankton that do photosynthesize make the higher of level of primary productivity of a water.

Average brightness in Agathis, Mahoni, Puspa, Ulin, Kenanga and Salam lakes range from 15.75 to $38.67 \mathrm{~cm}$. The range of brightness values that can support the productivity of aquatic organism, because of good brightness level to support aquatic organism productivity range from $30--65 \mathrm{~cm}$. Brightness is also affecting the primary productivity, if the brightness is reduced then the process of photosynthesis is inhibited so that the oxygen in the water decreases, which is oxygen required for the metabolism of aquatic organisms [1].

Dissolved Oxygen (DO) on average in Agathis, Mahoni, Puspa, Ulin, Kenanga and Salam lakes range from 0.15 to 2.23 $\mathrm{mg} / \mathrm{l}$. The range of Dissolved Oxygen (DO) is very low and barely able to support life aquatic organisms. Dissolved Oxygen (DO) concentration of the water is optimal for the survival of aquatic organisms at $5 \mathrm{mg} / \mathrm{l}$. The high activity of respiration of aquatic organisms that live in water as well as organic and inorganic material input into the lakes, which is dominated by household waste such as plastic waste, detergents or metal can result in high activity of decomposers organisms. The lower the content of Dissolved Oxygen (DO), the lower the number of aquatic organisms that can survive in waters that mainly phytoplankton. The low amount of phytoplankton that carry out photosynthesis effect on primary productivity level of water. Concentrations of nitrate $(\mathrm{N})$ and phosphate $(\mathrm{P})$ on average range in Agathis, Mahoni, Puspa, Ulin, Kenanga and Salam lakes, is from 4.54 to $25.7 \mathrm{mg} / \mathrm{l}$ and 0.0037 to 1.053 $\mathrm{mg} / \mathrm{l}$. High or low concentration of nitrate and phosphate can be affected by organic matter derived from household waste such as detergents and sewage waste organic fertilizer into the water.

\section{CONCLUSION}

Agathis, Mahoni, Puspa, Ulin, Kenanga and Salam lakes has potential as a carbon sink the average ranged from $0.442--$ $0.879 \mathrm{mgC} / \mathrm{m}^{3} /$ hour. The level of carbon uptake highest in situ Salam in the amount of $0.879 \mathrm{mgC} / \mathrm{m}^{3} /$ hour, while the lowest, Ulin contained in lakes in the amount of $0.442 \mathrm{mgC} / \mathrm{m}^{3} /$ hour. The results of the analysis of chlorophyll-a, chlorophyll-b and chlorophyll-c in six lakes University of Indonesia, Depok, west java, Indonesia, in a row has an average of $0.079 \mathrm{mg} / \mathrm{l}, 0.051$ $\mathrm{mg} / \mathrm{l}$ and $0.057 \mathrm{mg} / \mathrm{l}$. The correlation between concentration of chlorophyll and carbon total not always as positive correlation, that can be affected by several factor such as environment condition, ecosystem of aquatic organism, particularly phytoplankton concentration on the lakes.

\section{ACKNOWLEDGMENT}

Thanks to Drs. Wisnu Wardhana, M. Si as the supervisors in this study. Thanks to Department of Biology and Faculty of Math and Science, Universitas Indonesia for their supports to carry out this joint research works. Thanks to Muhamad Yassir Fathinsyah, Siti Azhyra Dwi Ayu, Anggun Aiyla Nova, for 
helping us in conducting this research and also thanks to $\mathrm{K} 3 \mathrm{~L}$ and PLK Universitas Indonesia, for helping us to this research.

\section{REFERENCES}

[1] Barus,T.A. 2004. Pengantar Limnologi, Studi Tentang Ekosistem Air Daratan. Jurusan Biologi. Fakultas MIPA USU. Medan.

[2] Bell, P. R. \& A. R. Hemsley. 2004. Green plants: their origin and diversity. $2^{\text {nd }}$ ed. Cambridge University Press, Cambridge: vii +331 pages.

[3] Cole, G. A. 1994. Textbook of Limnology. $4^{\text {th }}$ ed. Waveland Press, Inc., Illinois: xii+412 pages.

[4] Fennel,K \& E. Boss. 2003. Subsurface maxima of phytoplankton population and chlorophyll; Steady state solutions from a simple model. Limnology Oceanography 48(4): 1521-1534. https://doi.org/10.4319/lo.2003.48.4.1521

[5] Veronica, A., D. Arfiati., Soemarno \& A. Leksono. 2012. Komunitas Fitoplankton dan Faktor Lingkungan yang Memengaruhi Kelimpahannya di Sungai Hampalam, Kabupaten Kapuas. Seminar Nasional IX Pendidikan Biologi FKIP UNS 9(1): 421—426 pages. 